\title{
Rangeland experiments to parameterize the water erosion prediction project model: vegetation canopy cover effects
}

\author{
J.R. SIMANTON, M.A. WELTZ, AND H.D. LARSEN
}

\begin{abstract}
The Water Erosion Prediction Project (WEPP) is a new water erosion prediction technology being developed by the USDAAgricultural Research Service to replace the Universal Soil Loss Equation. Rangeland field experiments were designed to parameterize the WEPP rangeland erosion model. Included in the field experiments were plot treatments designed to separate direct from indirect effects of vegetation canopy on runoff and soil erosion. Nine rangeland sites from a wide range of soil and vegetation types were evaluated using rainfall simulation techniques. Natural versus clipped treatment surface characteristics and runoff and erosion responses were compared using regression analyses. These analyses showed that there were no significant differences between natural and clipped plot surface characteristics, runoff ratios, final infiltration rates, or initial rainfall abstractions. Erosion rates were different between treatments with the clipped plots having slightly less erosion than the natural plots. Results indicated that, under the rainfall conditions simulated, canopy cover was not directly contributing to initial abstractions through rainfall interception loss or significantly affecting runoff or erosion.
\end{abstract}

Key Words: soil loss, infiltration, runoff, interception losses, rainfall simulation

Rangeland vegetation parameters are important components in many hydrologic and erosion models. Vegetation parameter impacts to these models range from modifying soil moisture content as a function of plant water use (Wight 1983, Williams and Renard 1985) to dissipating rainfall energy by canopy cover interception (Wischmeier and Smith 1978). In 1985 the United States Department of Agriculture (USDA) initiated the Water Erosion Prediction Project (WEPP) (Foster 1987) to develop a processbased erosion prediction technology to replace the Universal Soil Loss Equation (Wischmeier and Smith 1978).

Vegetation parameters affect many WEPP erosion model components that are temporally updated: soil water content, soil surface cover, random and hydraulic roughness, and above and below ground biomass. The WEPP model will be parameterized from data collected over a 2-year period from both crop and rangeland sites throughout the United States. The WEPP rangeland field experiments were conducted over a wide range of soil/vegetation associations to develop relationships among rangeland soil properties, vegetation, land use, infiltration, runoff, soil erodibility, and soil loss. Included in the WEPP rangeland experimental design were treatments to determine soil erodibility adjustments to account for direct effects of vegetation canopy cover.

Numerous studies have been conducted to determine the role of vegetation canopy cover in runoff and erosion processes on range-

\footnotetext{
Authors are hydrologist, hydrologist, and hydrologic technician, respectively, USDA-ARS, Aridland Watershed Management Research Unit, 2000 E. Allen Road, Tucson, Arizona 85719

Acknowledgements. The authors thank the SCS personnel who were exceptionally helpful in site selection and evaluation; the University of California and U.S. Dept. of Energy for their cooperation and support; U.S. Bureau of Land Management for support and field assistance; and cooperating ARS personnel at: Boise, Idaho; Woodward, Okla.; Chickasha, Okla.; Sidney, Mont.; West Lafayette, Ind.; and Lincoln, Neb.

For their extremely hard work, dedication, and enthusiasm, a special thanks to the WEPP Rangeland Field Team of: Dr. Jeffry Stone, Ms. Donna Page, Mr. Robert Freitas, Ms. Wendy Tuggle, Mr. Arthur Dolphin, Mr. James Smith, Mr. William Rice, Ms. Gunilla Eagleton, Ms. Christine Christiansen, Mr. Richard Van Der Zweep, and Mr. Curtis Leet.

Manuscript accepted 16 September 1990
}

lands (e.g., Dadkhah and Gifford 1980, Branson et al. 1981, Blackburn et al. 1982). Results from many of these studies have been inconsistent because interactions of vegetation canopy cover and soil properties could not be separated with the experimental procedures used. Gifford (1978), using infiltrometer data from natural plots in Utah, found that canopy cover could account for up to $70 \%$ of the variance in coefficients of 3 infiltration equations. He assumed, however, that canopy cover, bare soil, soil bulk density, and total soil porosity were independent variables in his multiple regression analysis. The question remains: Does the canopy cover directly affect runoff and erosion or are the indirect effects associated with canopy cover such as increased litter cover, soil macro-porosity, soil organic matter, soil structure or reduced soil compaction the dominating factors? Busby and Gifford (1981) conducted experiments that separated canopy cover's direct and indirect effects on infiltration and erosion. They found that clipping crested wheatgrass (Agropyron cristatum) on a sandstonederived soil in southeastern Utah had no measurable affect on infiltration or sheet erosion rates. Johnson and Blackburn (1989), reported similar differences in average runoff and soil loss between natural and clipped treatments from sagebrush sites in Idaho. Their work, using the same experimental procedures developed for WEPP, was a direct contribution to the WEPP effort but their results were not used in our analysis.

The objective of this paper is to evaluate the direct effect of vegetation canopy cover on runoff, infiltration, and erosion as measured over a wide range of vegetation types, rangeland soils, and soil surface and canopy covers.

\section{Methods and Study Sites}

The WEPP rangeland field experiments used rainfall simulation on large plots to produce runoff, infiltration, and erosion data from 24 rangeland sites at 16 locations throughout the western United States. Cooperative studies among Agricultural Research Service (ARS) locations in Tucson, Ariz., and Boise, Idaho, and Utah State University in Logan, Utah, have contributed to the WEPP rangeland data base. Inputs from Soil Conservation Service (SCS), Forest Service (FS), Bureau of Land Management (BLM), and university range specialists were obtained to aid in selection of range sites that represented a wide range of soils and vegetation types.

Data from 9 of the 20 WEPP rangeland sites evaluated by the Tucson location were used in the analyses made in this paper (Tables 1 and 2). The excluded sites either had been clipped in the spring and fall for 3 to 5 years or did not have the clipped treatment (the site was grazed to less than $20 \mathrm{~mm}$ canopy height).

The rotating boom rainfall simulator (Swanson 1965) used in these experiments is trailer mounted and has ten $7.6 \mathrm{~m}$ booms radiating from a central stem. The booms supported $30 \mathrm{~V}$-Jet 80100 nozzles positioned at various distances from the stem. The nozzels spray continuously downward from an average height of 3 $\mathrm{m}$, move in a circular path over the plots and apply rainfall intensities of approximately $65 \mathrm{~mm} / \mathrm{hr}$ with drop-size distributions similar to natural rainfall. Intermittent rainfall impulses are produced at the plot surface as the booms pass over the plot. Raindrop impact energies are $77 \%$ of those of natural rainfall and rainfall 
Table 1. Latitude, longitude, elevation, average annual precipitation, frost free period (FFP) and aspect of rangeland sites.

\begin{tabular}{|c|c|c|c|c|c|c|c|c|c|}
\hline \multirow{2}{*}{$\frac{\text { Code }}{\text { D1 }}$} & \multirow{2}{*}{$\begin{array}{l}\text { Location } \\
\text { Chickasha, OK }\end{array}$} & \multicolumn{2}{|c|}{$\begin{array}{l}\text { Lat. } \\
\text { (N) }\end{array}$} & \multicolumn{2}{|c|}{$\begin{array}{l}\text { Long. } \\
\text { (W) }\end{array}$} & \multirow{2}{*}{$\begin{array}{c}\begin{array}{c}\text { Elev. } \\
(\mathrm{M})\end{array} \\
380\end{array}$} & \multirow{2}{*}{$\frac{\begin{array}{c}\text { Ppt. } \\
(\mathrm{mm})\end{array}}{800}$} & \multirow{2}{*}{$\begin{array}{c}\begin{array}{c}\text { FFP } \\
\text { (days) }\end{array} \\
210\end{array}$} & \multirow{2}{*}{$\frac{\text { Aspect }}{\text { SE }}$} \\
\hline & & 35 & 05 & 97 & 47 & & & & \\
\hline El & Ft. Supply, OK & 36 & 37 & 99 & 35 & 640 & 630 & 200 & $\mathbf{E}$ \\
\hline E3 & Ft. Supply, OK & 36 & 37 & 99 & 35 & 640 & 630 & 200 & $\mathbf{E}$ \\
\hline E4 & Freedom, OK & 36 & 52 & 99 & 08 & 550 & 650 & 200 & NW \\
\hline E5 & Freedom, OK & 36 & 52 & 99 & 08 & 550 & 650 & 200 & NW \\
\hline F1 & Sidney, MT & 47 & 50 & 104 & 16 & 610 & 360 & 120 & $\mathbf{E}$ \\
\hline GI & Meeker, CO & 40 & 14 & 108 & 34 & 1760 & 200 & 90 & $\mathbf{S}$ \\
\hline $\mathrm{Hl}$ & Cottonwood, SD & 43 & 57 & 101 & 52 & 745 & 390 & 130 & W \\
\hline $\mathbf{K} \mathbf{l}$ & Susanville, CA & 40 & 37 & 120 & 37 & 1770 & 380 & 100 & $\mathbf{N}$ \\
\hline
\end{tabular}

spatial distribution over each plot had a coefficient of variation of less than $10 \%$. Six nonrecording raingages are used on each plot to measure rainfall amounts and distribution. A recording raingage was placed between paired plots to measure rainfall intensity (Fig. 1). Plot treatments consisted of natural and clipped (canopy clipped to $20 \mathrm{~mm}$ height and clippings removed). Natural plot data were used to develop erosion, runoff, and infiltration relationships among types and degrees of vegetation and soil surface covers. The clipped plot data were used to separate canopy cover effects from soil surface cover effects on runoff and erosion. The clipped treat-

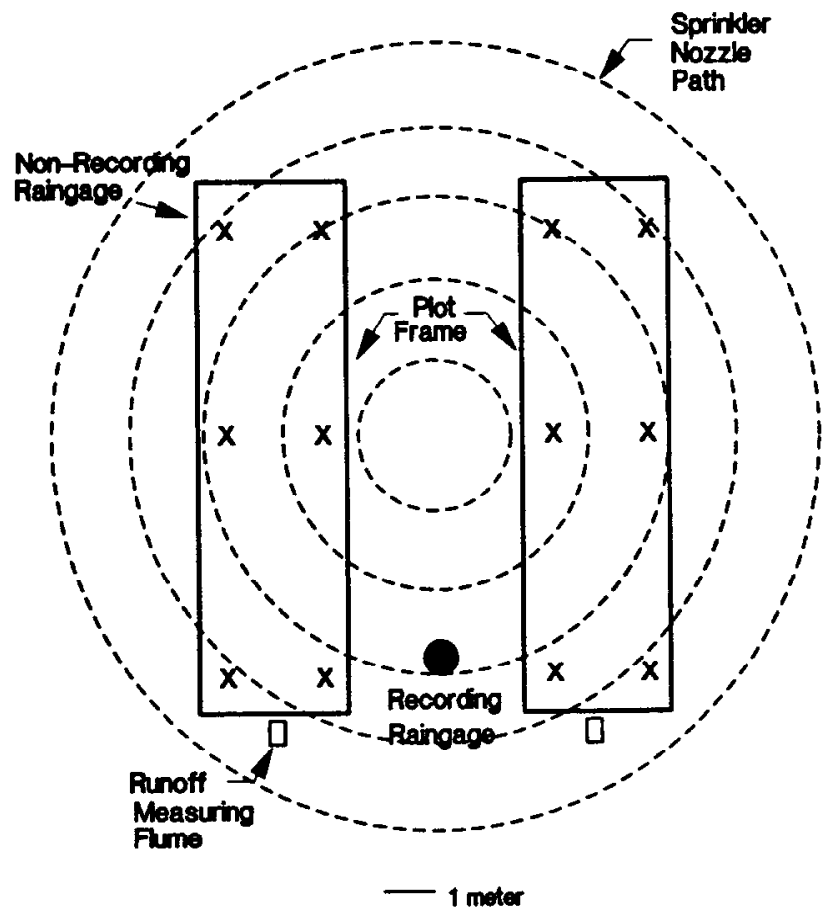

Fig. 1. Schematic of plot pair layout showing path of nozzles and location of recording and nonrecording raingages. ment was not intended to simulate grazing or long term canopy cover removal effects.

A 30-min rainfall simulation $(65 \mathrm{~mm} / \mathrm{hr})$ was made on each plot. Twenty-four hours prior to this simulation the plots were prewet to field capacity soil moisture conditions using a 60 -min rainfall simulation ( $65 \mathrm{~mm} / \mathrm{hr}$ ). Rainfall simulations were made in the spring and summer of 1987 and 1988 except at site K1 when a fall 1987 evaluation was made.

At each rangeland site there were 2 plots of each treatment except sites E3, E4, E5, and K1, which had only 1 clipped plot. These 4 sites were limited in area, and suitable plot locations could not be found. Each plot was $3.05 \mathrm{~m}$ wide by $10.7 \mathrm{~m}$ long with the long axis parallel to the slope. This size was needed to reduce the ratio of plot border to the total plot area and to evaluate rill erosion and sediment transport and deposition associated with sheet and concentrated flow. The plots were paired so 2 plots were evaluated simultaneously (Fig. 1).

Metal sheets, $15 \mathrm{~cm}$ wide, were used to form the sides and upper end of each plot. The sheets were inserted $3 \mathrm{~cm}$ into the soil creating a $12 \mathrm{~cm}$ high border. The downslope end of the plot had a $20 \mathrm{~cm}$ wide metal sheet, with a sill plate formed on the upper edge, inserted into the soil so that the sill plate was flush with the soil surface. Runoff and sediment from the plot were diverted into a runoff measuring flume by troughs mounted below the sill plate.

Plot runoff was measured with a precalibrated runoff measuring flume that was set at the plot trough exit. Flow depths in the flume were continuously recorded by a pressure transducer bubble gage. Time to ponding, initial and ending runoff times were noted on field data sheets. Hydrographs were produced using the flume's depth/discharge rating table and then integrated to determine plot runoff volumes and rates.

During runoff, periodic water/sediment samples ( 1 liter) were manually collected from the flume's exit. Sampling intervals depended on hydrograph shape, with 1-2 min intervals between samples on the rising and falling portions of the hydrograph and longer intervals during runoff equilibrium. Sedigraphs were produced by comparing sediment concentrations to the hydrograph and integrated to produce sediment yields.

Table 2. Major land resource area (MLRA), plant community, percent canopy cover, range site and range condition of rangeland sites.

\begin{tabular}{lclclc}
\hline \hline Code & MLRA & Plant Community & Percent canopy cover & Range site & Range condition \\
\hline D1 & $80 A$ & Tallgrass Prairie & 50 & Loamy Prairie & Good \\
E1 & 78 & Mixedgrass Prairie & 36 & Dune & Good \\
E3 & 78 & Mixedgrass Prairie & 39 & Dune & Excellent \\
E4 & 78 & Mixedgrass Prairie & 89 & Loamy Prairie \\
E5 & 78 & Mixedgrass Prairie & 38 & Loamy & Fair \\
F1 & 54 & Mixedgrass Prairie & 23 & Silty \\
G1 & 34 & Salt Desert Shrub & 58 & Clayey Slopes & Good \\
H1 & $63 A$ & Mixedgrass Prairie & 38 & Clayey & Loam \\
K1 & 21 & Great Basin Shrub Steepe & 39 & Excellent
\end{tabular}




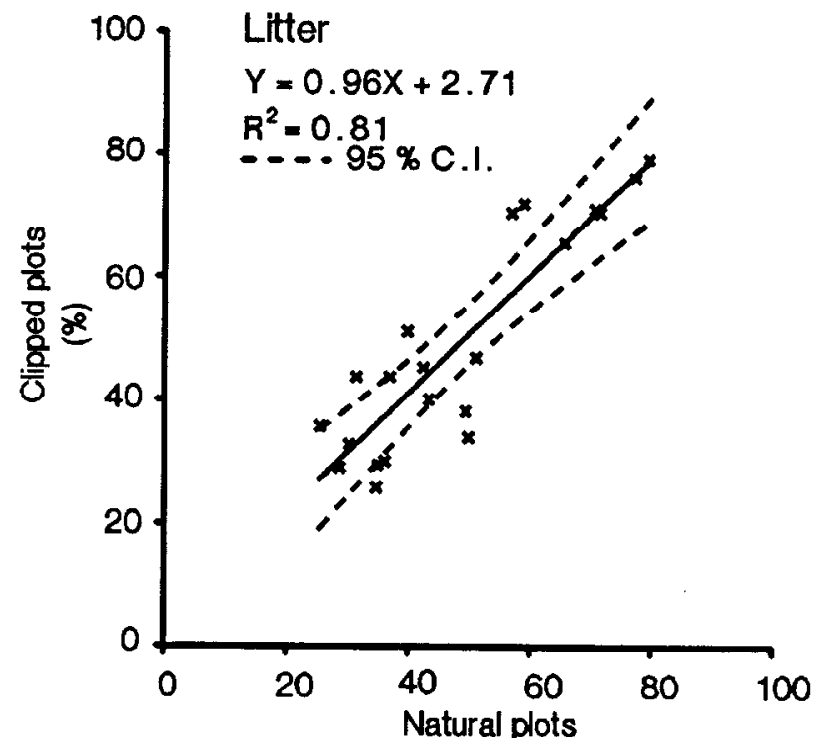

(\%)

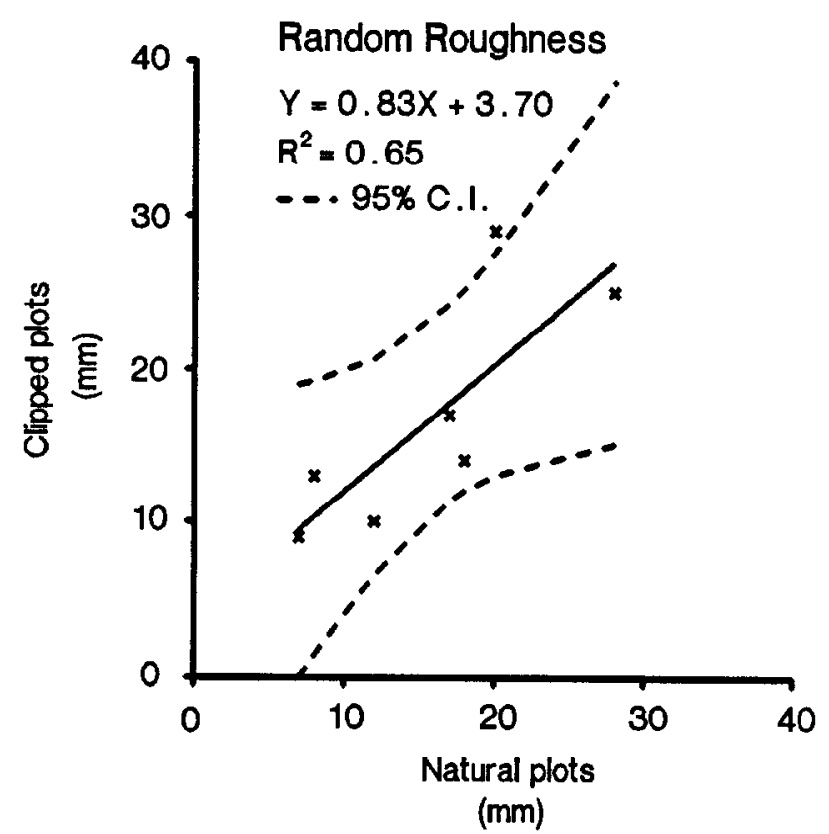

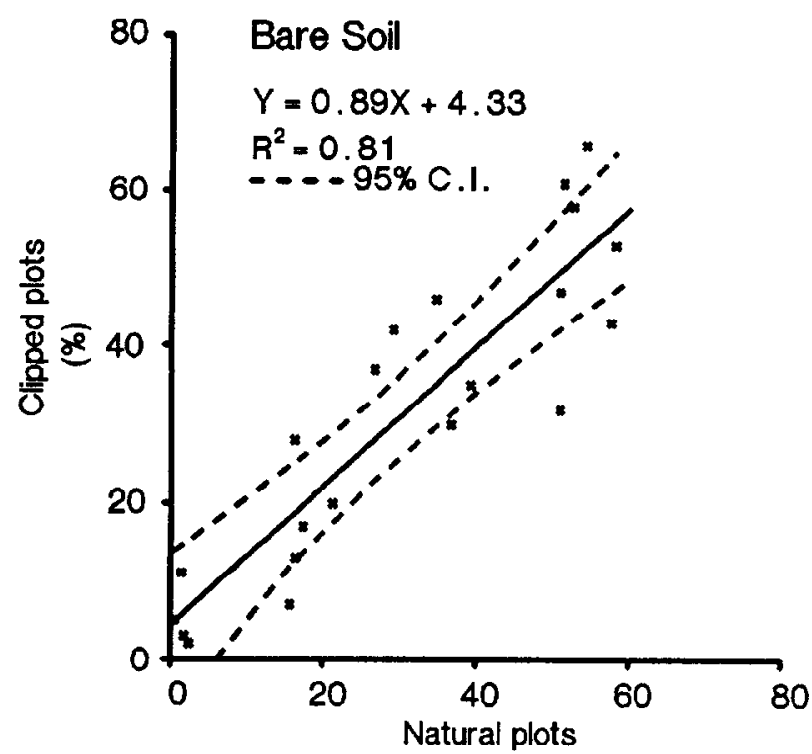

(\%)

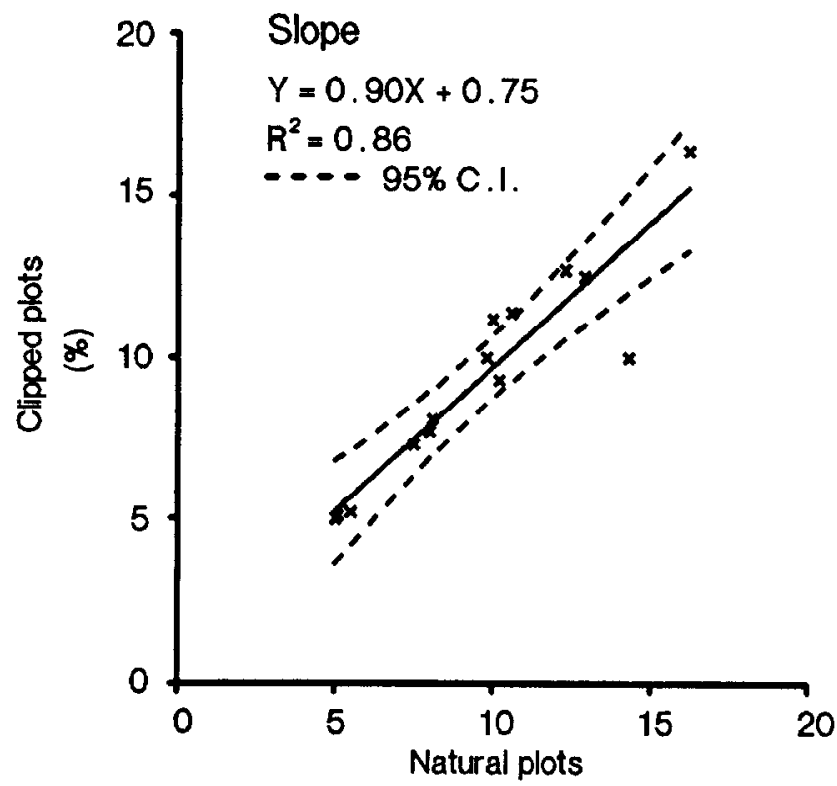

(\%)

Fig. 2. Comparison of natural and clipped plot litter and bare soil cover, random roughness, and slope with regression equation and best fit line, coefficient of determination $\left(R^{2}\right)$ and $95 \%$ confidence intervals (C.I.).

After consultation with land owners and/or operators, prior and current land use (i.e., grazed, nongrazed, and type of grazing animal) were recorded for each site. The SCS personnel provided range site descriptions and range condition classification each year at the time simulations were made.

Plot ground surface and canopy cover were characterized by using a vertical 49 pin-point frame before and after plot treatment. For each point, 2 characteristics were measured: canopy cover and ground surface cover. There were 10 transects per plot for a total of 490 ground surface points and a possible 490 canopy cover points (Simanton and Renard 1982). Canopy cover was determined as the first aerial contact of vegetation as the pin was lowered to the ground surface. Ground surface cover characteristics included: bare soil, gravel and rocks ( $>5 \mathrm{~mm}$ ), litter, cryptogams, and plant basal cover. To minimize soil surface disturbance or compaction and prevent trampling of plants during plot characterization, an elevated metal walkway was placed across the plot.

Soil moisture content was determined gravimetically from com- posite soil moisture samples taken at the $0-5 \mathrm{~cm}$ depth and from 5 $\mathrm{cm}$ to wetting front or $20 \mathrm{~cm}$ depth, whichever was less. Plot random roughness was determined only in 1988 using a 21-pin point frame with pins spaced $9 \mathrm{~cm}$ apart (Kincaid and Williams 1966). Ten transects were taken horizontally across the plot for a total of 210 readings. The standard deviation of pin heights $(\mathrm{mm})$ across each transect was averaged among transects to give a plot random roughness index.

Even though there was considerable effort in the site selection process to ensure homogeneity in soil and vegetation properties, variability within the site can occur (Devaurs and Gifford 1984). Comparisons of natural and clipped plot characteristics of percent litter, exposed soil, slope, and random roughness were made to strengthen the assumption that each site was homogeneous and that canopy cover differences (natural vs. clipped) would account for differences in runoff and erosion responses.

Although run times and rainfall intensities were to be the same for each rainfall simulation and plot, water supply and wind prob- 
lems sometimes caused different rainfall volumes to be applied. To account for these application differences in comparing plot runoff responses, a runoff ratio $(\mathrm{Q} / \mathrm{P})$ was determined for each plot by dividing total runoff volume $(\mathrm{Q})$ by total rainfall volume $(\mathrm{P})$ applied during the simulation. Erosion rates $(\mathrm{Kg} / \mathrm{ha} / \mathrm{Qmm})$ were calculated by dividing the plot total sediment yield by the total runoff volume. Final infiltration rate $(\mathrm{mm} / \mathrm{hr})$ was the difference between the rainfall rate and equilibrium runoff rate. Initial rainfall abstraction ( $\mathrm{mm}$ ) was calculated as the rainfall volume applied to the plot before runoff occurred. Initial infiltration rate was calculated as the difference between the rainfall rate $(\mathrm{mm} / \mathrm{hr})$ and the runoff rate 5 minutes after runoff began. Comparisons of runoff ratios, erosion rates, initial and final infiltration rates, initial rainfall abstraction, soil moisture content, and plot surface characteristics between paired natural and clipped plots were made using linear regression analysis and the corresponding $95 \%$ confidence interval of the regression line slope and intercept.

Except for comparisons of random roughness, soil moisture, and plot slope, 21 natural/clipped pairs were available for comparison in the regression analysis. Random roughness was measured only in 1988 so there were only 7 pairs available. Soil moisture data were lost for site $\mathrm{G} 1$ thus giving only 19 pairs for comparison. Plot slopes did not change between 1987 and 1988 so the plots reevaluated in 1988 were not included in the slope comparisons.

\section{Rangeland Sites}

Tables 3 and 4 detail the soil and vegetation types of the 9 rangeland sites evaluated. Five sites were selected in Oklahoma

Table 3. Soil series, classification and texture of rangeland sites.

\begin{tabular}{|c|c|c|c|}
\hline Code & Soil series & Soil classification & Soil texture \\
\hline D1 & Grant & $\begin{array}{l}\text { Fine-silty, mixed, thermic } \\
\text { Udic Argiustoll }\end{array}$ & Loam \\
\hline E1 & Pratt & $\begin{array}{l}\text { Sandy, mixed, thermic } \\
\text { Psammentic Haplustalf }\end{array}$ & Loamy fine sand \\
\hline E3 & Tivoli & $\begin{array}{l}\text { Mixed, thermic, Typic } \\
\text { Ustipsamment }\end{array}$ & Fine sand \\
\hline E4 & Woodward & $\begin{array}{l}\text { Coarse-silty, mixed, thermic, } \\
\text { Typic Ustochrept }\end{array}$ & $\begin{array}{l}\text { Very fine sandy } \\
\text { loam }\end{array}$ \\
\hline E5 & Woodward & $\begin{array}{l}\text { Coarse-silty, mixed, thermic, } \\
\text { Typic Ustochrept }\end{array}$ & $\begin{array}{l}\text { Very fine sandy } \\
\text { loam }\end{array}$ \\
\hline F1 & Vida & $\begin{array}{l}\text { Fine-loamy, mixed Typic } \\
\text { Argiboroll }\end{array}$ & Loam \\
\hline G1 & Degater & $\begin{array}{l}\text { Fine, mixed, mesic } \\
\text { Typic Camborthid }\end{array}$ & Silty clay \\
\hline H1 & Pierre & $\begin{array}{l}\text { Very-fine, montmorillonitic, } \\
\text { mesic Typic Torrent }\end{array}$ & Clay \\
\hline $\mathbf{K} 1$ & Jauriga & $\begin{array}{l}\text { Fine-loamy, mixed, mesic } \\
\text { Typic Argixeroll }\end{array}$ & $\begin{array}{l}\text { Gravelly sandy } \\
\text { loam }\end{array}$ \\
\hline
\end{tabular}

and represent grass and shrub prairies of the Great Plains. The site near Chickasha (D1) is typical of native tallgrass prairie and had been lightly grazed prior to the 1987 evaluation and moderately grazed prior to the 1988 evaluation. The site is located on ARS watershed R-5 which has been used for extensive hydrologic and erosion studies (Sharma et al. 1980). The 2 sites at Ft. Supply (E1 and E3) are on the ARS Ranch Horse pasture and represent different range conditions on mixedgrass prairie that had intermixed brush (See Rhoades et al. 1964 for additional description). The sites are less than $1 \mathrm{~km}$ apart and both had been grazed. Two sites at Freedom (E4 and E5) were adjacent to one another separated only by a fence. E4 had not been grazed in over 10 years and was in an excellent range condition class. E5 had been continuously heavily grazed and was classified as fair range condition. The site near Sidney, Mont., (F1) had been lightly grazed and represents rangelands whose soil surface cover includes large amounts of club mosses. The salt desert shrub site near Meeker, Colo., (G1)
Table 4. Common and scientific names of major vegetation species of rangeland sites.

\begin{tabular}{|c|c|c|c|}
\hline Code & Common name & Genus & Species \& Author \\
\hline D1 & $\begin{array}{l}\text { Little bluestem } \\
\text { Indiangrass } \\
\text { Switchgrass } \\
\text { Sideoats grama }\end{array}$ & $\begin{array}{l}\text { Schizachyrium } \\
\text { Sorghastrum } \\
\text { Panicum } \\
\text { Bouteloua }\end{array}$ & $\begin{array}{l}\text { scoparium (Michx.) Nash } \\
\text { nutans }(\mathrm{L} .) \text { Nash } \\
\text { virgatum } \mathrm{L} \\
\text { curtipendula (Michx.) Torr }\end{array}$ \\
\hline E1 & $\begin{array}{l}\text { Sand lovegrass } \\
\text { Sand paspalum } \\
\text { Blue grama } \\
\text { Sand sage }\end{array}$ & $\begin{array}{l}\text { Eragrostis } \\
\text { Paspalum } \\
\text { Bouteloua } \\
\text { Artemisia }\end{array}$ & $\begin{array}{l}\text { trichodes (Nutt.) A. Wood } \\
\text { stramineum (Michx.) Nash } \\
\text { gracilis (H.B.K.) Lag } \\
\text { filifolia Torr }\end{array}$ \\
\hline E3 & $\begin{array}{l}\text { Sand lovegrass } \\
\text { Sand paspalum } \\
\text { Blue grama } \\
\text { Camphor weed } \\
\text { Spiderwort } \\
\text { Switchgrass } \\
\text { Sand sage }\end{array}$ & $\begin{array}{l}\text { Eragrostis } \\
\text { Paspalum } \\
\text { Bouteloua } \\
\text { Heterotheca } \\
\text { Tradescantia } \\
\text { Panicum } \\
\text { Artemisia }\end{array}$ & $\begin{array}{l}\text { trichodes (Nutt.) A. Wood } \\
\text { stramineum (Michx.) Nash } \\
\text { gracilis (H.B.K.) Lag } \\
\text { subaxillaris (Lam.) Britt. \& Rusby } \\
\text { occidentalis (Britton) Symth } \\
\text { virgatum L. } \\
\text { filifolia Torr }\end{array}$ \\
\hline E4 & $\begin{array}{l}\text { Little bluestem } \\
\text { Sunnel bluestem } \\
\text { Indiangrass }\end{array}$ & $\begin{array}{l}\text { Schizachyrium } \\
\text { Andropogon } \\
\text { Sorghastrum }\end{array}$ & $\begin{array}{l}\text { scoparium (Michx.) Nash } \\
\text { Hallii Hack } \\
\text { nutans (L.) Nash }\end{array}$ \\
\hline E5 & $\begin{array}{l}\text { Sideoats grama } \\
\text { Hairy grama } \\
\text { Silver bluestem }\end{array}$ & $\begin{array}{l}\text { Bouteloua } \\
\text { Bouteloua } \\
\text { Bothriochloa }\end{array}$ & $\begin{array}{l}\text { curtipendula (Michx.) Torr } \\
\text { hirsuta Lag } \\
\text { saccharoides (Swartz) Rybd }\end{array}$ \\
\hline F1 & $\begin{array}{l}\text { Dense clubmass } \\
\text { Blue grama } \\
\text { W. wheatgrass } \\
\text { Needle \& thread }\end{array}$ & $\begin{array}{l}\text { Selaginella } \\
\text { Bouteloua } \\
\text { Agropyron } \\
\text { Stipa }\end{array}$ & $\begin{array}{l}\text { densa Rybd } \\
\text { gracilis (H.B.K.) Lag } \\
\text { Smithii Rydb } \\
\text { comata Trin. \& Rupr }\end{array}$ \\
\hline G1 & $\begin{array}{l}\text { W. wheatgrass } \\
\text { Salina wildrye } \\
\text { Wy. big sage- } \\
\text { brush }\end{array}$ & $\begin{array}{l}\text { Agropyron } \\
\text { Elymus } \\
\text { Artemisia }\end{array}$ & $\begin{array}{l}\text { Smithii Rybd } \\
\text { salinus M.E. Jones } \\
\text { tridentata Nutt }\end{array}$ \\
\hline & Shadscale & Atriplex & confertifolia (Torr. \& Frem) Wats \\
\hline H1 & $\begin{array}{l}\text { W. wheatgrass } \\
\text { Green needle- } \\
\text { grass }\end{array}$ & $\begin{array}{l}\text { Agropyron } \\
\text { Stipa }\end{array}$ & $\begin{array}{l}\text { Smithii Rydb } \\
\text { viridula Trin }\end{array}$ \\
\hline & Globemallow & Sphaeralcea & coccinea (Pursh) Rydb \\
\hline K1 & $\begin{array}{l}\text { Idaho fescue } \\
\text { Squirreltail } \\
\text { Wolly mules } \\
\quad \text { ears }\end{array}$ & $\begin{array}{l}\text { Festuca } \\
\text { Sitanion } \\
\text { Wyethia }\end{array}$ & $\begin{array}{l}\text { idahoensis Elmer } \\
\text { hystrix (Nutt) J.G. Smith } \\
\text { mollis Gray }\end{array}$ \\
\hline & $\begin{array}{l}\text { Big sagebrush } \\
\text { Rabbitbrush } \\
\text { W. needlegrass }\end{array}$ & $\begin{array}{l}\text { Artemisia } \\
\text { Chrysothamnus } \\
\text { Stipa }\end{array}$ & $\begin{array}{l}\text { tridentata Nutt } \\
\text { viscidiflorus (Hook) Nutt } \\
\text { Occidentalis Thurb. ex S. Wats }\end{array}$ \\
\hline
\end{tabular}

had not been grazed within a year of the evaluation. This site represents a rangeland soil that is susceptible to rill formation. The grassland site near Cottonwood, S.Dak., (H1) was lightly grazed prior to 1987 and moderately grazed prior to the 1988 evaluations. The site is located on the Range and Livestock Experiment Station operated by the South Dakota State University at Brookings (see Hanson et al. 1978). The brush site (K1) in the BLM's Eagle Lake Resource Area was about $45 \mathrm{~km}$ north of Susanville, Calif. The site had not been grazed for 1 year prior to evaluation.

\section{Results}

Plot characteristic comparisons of litter, bare soil, random roughness, and slope are shown in Figure 2. The regressions of these comparisons have line slope coefficients of nearly 1.0 and relatively small intercepts. Confidence interval tests at the $95 \%$ level showed that in all plot characteristic comparisons the regression intercept was not different than zero and the regression slope was not different than one, indicating that measured plot characteristics were not significantly different between the 2 treatments. Similar regression results were found for runoff ratios, final infiltration rates, soil moisture contents, initial abstractions, and initial infiltration rates (Fig. 3). Erosion rates between the natural and clipped plots were different (Fig. 3). Though the intercept of the erosion rate comparison was not different from zero, the regression 

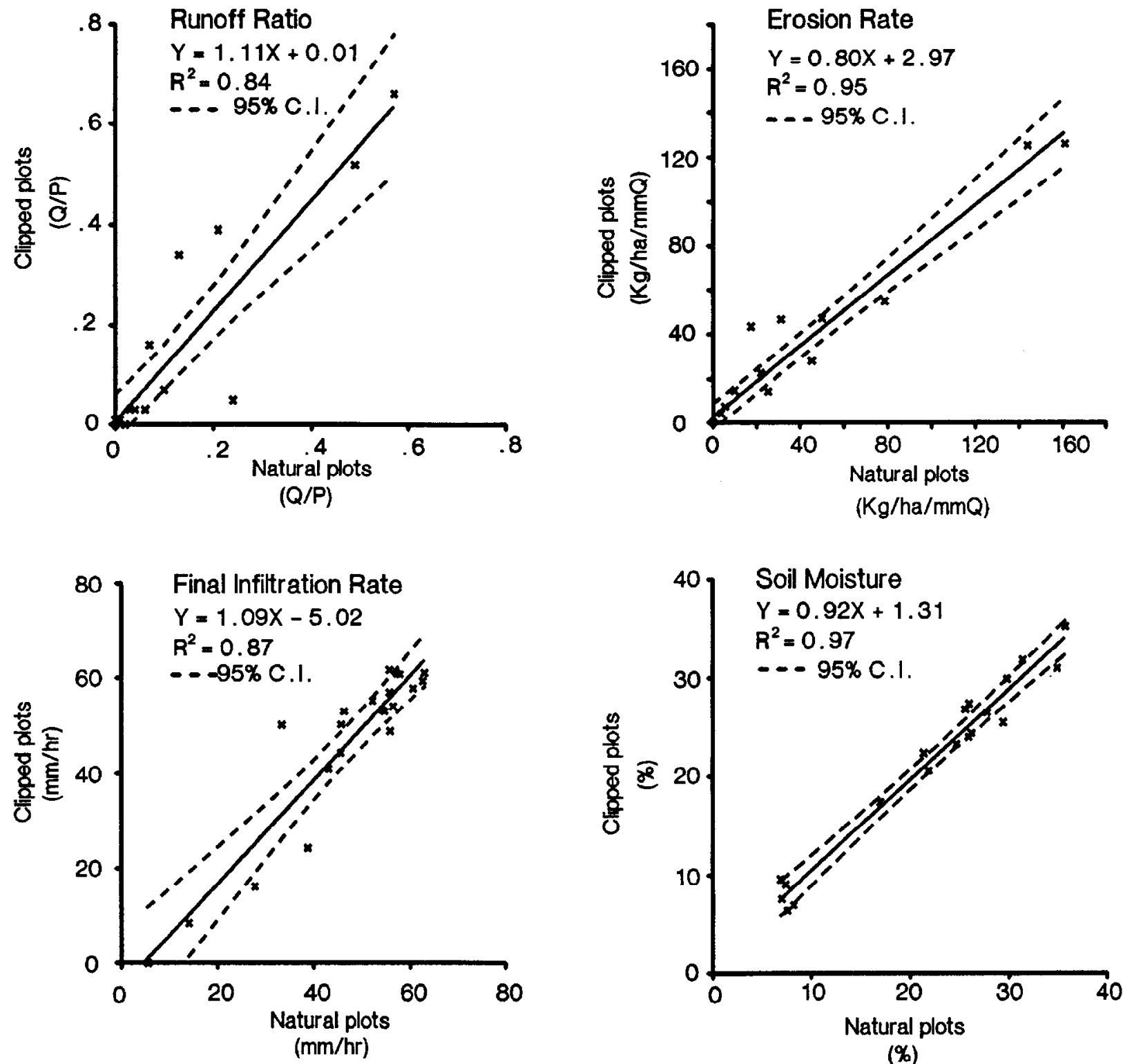

(\%)
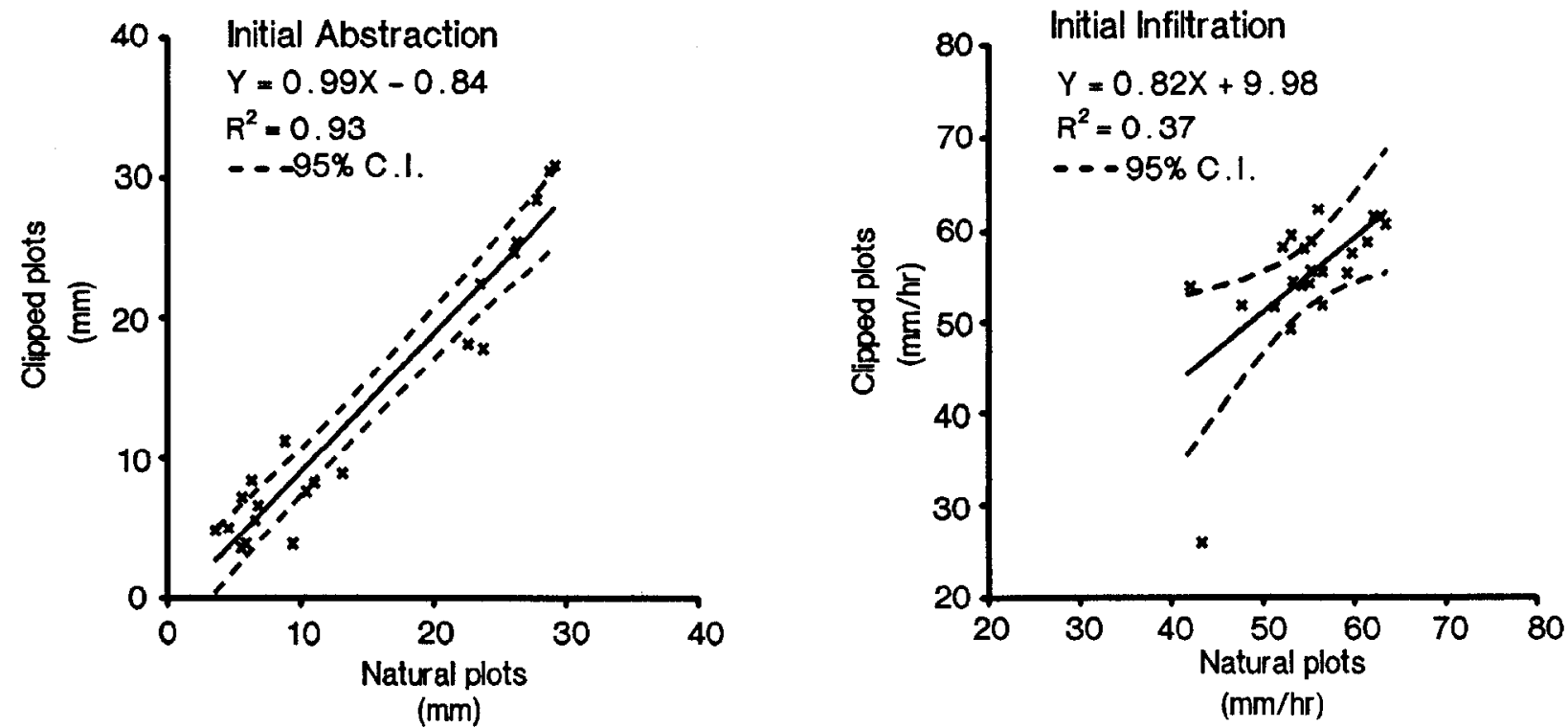

Fig. 3. Comparison of natural and clipped plot runoff ratios (Q/P), erosion rates, final infiltration rate, soil moisture, initial abstraction, and initial infiltration with regression equation and best fit line, coefficient of determination ( $R^{2}$ ) and $95 \%$ confidence interval (C.I.). 
line slope was different from 1 . The regression line slope of less than 1 and the relatively small intercept indicate that the clipped plots had an erosion rate less than the natural plots.

The 2 relatively large runoff ratios in Figure 3 are from site D1 for the 1987 evaluations and cannot be explained by analysis of data collected at the site. The 1988 evaluation of this site produced runoff ratios of around 20\% those found in 1987 with 1 of the natural plots in 1988 having a runoff ratio nearly 5 times that of its companion clipped plot. The initial abstraction graph in Figure 3 shows 2 distinct groupings of points. The high initial abstractions were associated with sites with either very porous soil (E1 and E3) or had been lightly or ungrazed 2 or more years prior to our evaluations (E4 and $1987 \mathrm{H1}$ ). The 2 extreme erosion rate points on the erosion rate graph in Figure 3 represent erosion rates from the G1 site. These relatively high erosion rates were ascribed to rill erosion. This site was the only site with noticeable rills on the plots before and after the rainfall simulations. Meyer et al. (1975) found, in rainfall simulation studies on tilled $6 \%$ sloped plots, that rilled plots produced about 3.4 times the soil loss as nonrilled plots. The G1 plots, sloped at 9 to $11 \%$, produced 3.3 times the average erosion rate of comparably sloped plots at other sites evaluated (sites F1 and $\mathrm{K} 1$ ).

\section{Discussion}

The assumption of site homogeneity is reinforced by the comparisons made of litter, exposed soil, slope, and random roughness. The similarity in soil moisture eliminates moisture effects and helps isolate the canopy cover effects. Factors not quantified such as distribution of vegetation and ground surface cover on each plot could have an effect on plot runoff and erosion response. Because plot treatments were randomly imposed at each site, these effects should also be random and not be biased for either treatment.

Final infiltration rate is not only a function of soil properties and ground surface cover but also a function of rainfall application rate. If, in a rainfall simulation under field capacity soil moisture conditions, application rate does not substantially exceed the infiltration rate, runoff equilibrium may not occur or occur late in the rainfall simulation. This would indicate that the final infiltration rate was being limited by the application rate rather than inherent soil properties. This was the situation at sites E1 and E3 where runoff did not occur during the simulation and the infiltration rates for these soils have been reported to range from 55 to $270 \mathrm{~mm} / \mathrm{hr}$ (Rhoades et al. 1964). Runoff equilibrium during our rainfall simulations was usually reached 10 to 15 minutes into the 30 minute run. This relatively short period to reach runoff equilibrium indicates that soil properties were controlling the final infiltration rate and rainfall application rate was not limiting.

Initial rainfall abstractions are a function of the soil initial infiltration rate, surface roughness and storage, and interception losses to vegetation canopy (USDA, SCS 1972). These abstractions were nearly identical for the natural and clipped plots as indicated by the very low intercept $(-0.84)$ and 0.99 regression slope. Though infiltration rate affects initial abstractions, comparisions of initial infiltration rate indicated that there were no differences in the rate between the natural and clipped plots. There was no difference in litter, bare soil, random roughness, or initial abstractions between treatments. As a result, it can be inferred that interception loss to canopy cover was not a significant component to initial abstraction. Interception losses are more significant under conditions of lower rainfall intensities and amounts than those used in this study (Thurow et al. 1987).

The significance of canopy cover in erosion prediction models is small compared to ground surface cover (Table 10, Wischmeier and Smith 1978). Canopy cover's direct influence on erosion is through its dissipation of raindrop energy with the magnitude of this influence dependent on the ground surface condition found under the canopy. The larger the percent bare soil under the canopy the larger the canopy cover effect (Wischmeier and Smith 1978). Percent bare soil on the rangeland natural and clipped plots averaged $30.6 \%$ and of this total, only $8 \%$ was under canopy. Under this condition and assuming only bare soil would be detached by raindrops, the clipped plot sediment yield would not be significantly affected by the soil eroded from the now canopy-free bare soil that was once under the canopy. Khan et al. (1988) found that as canopy cover height increased from $0.25 \mathrm{~m}$ to $1.0 \mathrm{~m}$, the erosion rate also increased. In our study, the clipped plots had a canopy height of $0.02 \mathrm{~m}$ and the natural plots'canopy height could be as great as $1 \mathrm{~m}$. This may explain the slightly greater erosion rates from our natural plots.

\section{Conclusions}

The clipped treatment in the WEPP rangeland experiments was designed to separate interacting relationships among vegetation canopy cover and runoff, infiltration, and erosion into direct and indirect effects. Because the same procedures, plot size, and rainfall simulator were used in the WEPP rangeland field experiments, the unique data set allows direct comparisons of runoff and erosion responses over a wide variety of rangeland conditions, soils and vegetation types. Data from the WEPP rangeland experiments represent a wide range of soils and vegetation types and can provide a better understanding of the processes involved in vegetation/ runoff/erosion interactions.

Comparisons made in this paper indicate, that under simulated rainfall conditions and soil and vegetation types evaluated, canopy cover has little direct effect on runoff, infiltration, initial abstractions, and erosion rate. Canopy cover's direct contributions to interception losses and soil surface protection from raindrop impact are not large in rangeland runoff and erosion responses. Indirect canopy cover effects such as desirable levels of soil structure, organic matter, and surface litter (Wilcox et al. 1988) are important contributors to rangeland productivity and soil and water conservation.

\section{Literature Cited}

Blackburn, W.H., R.W. Knight, and M.K. Wood. 1982. Impacts of grazing on watersheds a state of knowledge. Texas Agr. Exp. Sta. Pub. MP 1496.

Branson, F.A., G.F. Gifford, K.G. Renard, and R.F. Hadley. 1981. Rangeland hydrology. Soc. Range Manage. Denver, Colo.

Busby, F.E., and G.F. Gifford. 1981. Effects of livestock grazing on infiltration and erosion rates measured on chained and unchained pinyonjuniper sites in southeastern Utah. J. Range Manage. 34:400-405.

Dadkhah, M., and G.F. Gifford. 1980. Influence of vegetation, rock cover, and trampling on infiltration rates and sediment production. Water Resources Bull., Amer. Water Resource Assoc. 16:979-986.

Devaurs, M., and G.F. Gifford. 1984. Variability of infiltration within large runoff plots on rangelands. J. Range Manage. 37:523-528.

Foster, G.R. (Compiler). 1987. User Requirements: USDA-Water Erosion Prediction Project (WEPP). NSERL Rep. 1. Nat. Soil Erosion Res. Lab., USDA-ARS, W. Lafayette, Ind.

Gifford, G.F. 1978. Use of infiltration equation coefficients as an aid in defining hydrologic impacts of range management schemes. J. Range Manage. 31:115-117.

Johnson, C.W., and W.H. Blackburn. 1989. Factors contributing to sagebrush rangeland soil loss. Trans. Amer. Soc. Agr. Engr. 32:155-160.

Khan, M.J., E.J. Monke, and G.R. Foster. 1988. Mulch cover and canopy effect on soil loss. Trans. of the Amer. Soc. Agr. Engr. 31:706-711.

Kincaid, D.R., and G. Williams. 1966. Rainfall effects on soil surface characteristics following range improvement treatments. J. Range Manage. 19:346-351.

Hanson, C.L., A.R. Kuhlman, and J.K. Lewis. 1978. Effect of grazing intensity and range condition on hydrology of western South Dakota range. Bull. 647, S.D. Agr. Exp. Sta., Brookings. 
Meyer, L.D., G.R. Foster, and M.J.M. Romkens. 1975. Source of soil eroded by water from upland slopes. p. 177-189. In: Present and Prospective Technology for Predicting Sediment Yields and Sources, Proc. Sediment-Yield Workshop, USDA Sediment Lab., Oxford, Miss., Nov. 28-30. ARS-S-40.

Rhoades, E.D., L.F. Locke, H.M. Taylor, and E.H. Mcllvain. 1964. Water intake on a sandy range as affected by 20 years of differential cattle stocking rates. J. Range Manage. 17:185-190.

Sharma, M.L., G.A. Gander, and C.G. Hunt. 1980. Spatial variability of infiltration in a watershed. J. Hydrol. 45:101-122.

Simanton, J.R., and K.G. Renard. 1982. Seasonal change in infiltration and erosion from USLE plots in southeastern Arizona. Hydrology and Water Resources in Arizona and the Southwest, Office of Arid Land Studies, Univ. of Ariz., Tucson. 12:37-46.

Swanson, N.P. 1965. Rotating-boom rainfall simulator. Trans. Amer. Soc. Agr. Engr. 8:71-72.
Thurow, T.L., W.H. Blackburn, S.D. Warren, and C.A. Taylor, Jr. 1987. Rainfall interception by midgrass, shortgrass, and live oak mottes. J. Range Manage. 40:455-460.

USDA, Soil Conservation Service. 1972. Section 4, Hydrology, National Engineering Handbook. Washington, D.C.

Wight, J.R., (ed.) 1983. SPUR - Simulation of Production and Utilization of Rangelands: A Rangeland Model for Management and Research. USDA Misc. Pub. 1431.

Wilcox, B.P., M.K. Wood, and J.M. Tromble. 1988. Factors influencing infiltrability of semiarid mountain slopes. J. Range Manage. 41:197-206.

Williams, J.R, and K.G. Renard. 1985. Assessments of soil erosion and crop productivity with process models (EPIC) pp. 67-103. In: R.F. Follett and B.A. Stewart (eds). Soil Erosion and Crop Productivity. Amer. Soc. Agron., Crop Sci. Soc. Amer., Soil Sci. Soc. Amer., Madison, Wis.

Wischmeier, W.H., and D.D. Smith. 1978. Predicting rainfall erosion losses-a guide to conservation planning. USDA Agr. Handbk. No. 537. 